\title{
妊娠期における睡眠の主観的評価に関する研究
}

\section{Subjective Estimation of Sleep Pattern during Pregnancy}

\author{
堀内成子 (Shigeko HORIUCHI) ${ }^{*}$ 近 藤 潤 子 (Junko KONDO)* \\ 大川章子 (Akiko OKAWA)* 石井ひとみ (Hitomi ISHII) \\ 大久保 功子 (Noriko OKUBO)*
}

要 約

本研究は, 妊娠の進行に伴う睡眠の変化を明らかにするために，妊婦の睡眠の主観的評価を分析する こ上を目的に行った。調査票は「入眠および睡眠中の関連因子群」, 「起床時の関連因子群」,「睡眠全体 の満足度」、「睡眠に関寸る影響因子」を含好構成し、289例の妊婦から有効回答を得た。

その結果, 妊娠の進行に伴う変化では, 初期には非妊期に比べて途中覚醒が多く,「眠い」という睡眠 に対する欲求が強く現れていた。中期になると, 初期に比べて睡眠に対する欲求は落ち着きを示してい た。末期になると，寝つきが悪くなる・眠りが浅くなる・時間が不足する・途中覚醒が多くなるという 状態から, 睡眠全体に不満感が高まるという関係が示された。

初座婦では, 妊娠初期に夜中の途中覚醒に対して「いやだ」という否定的な回答が多く, 妊娠が進行 寸るにつれて, その比率は減少していた。

影響因子として, 妊娠に伴う身体変化のほかに, 家庭のサポートが認められた。

\section{Abstract}

In order to identify the changes on sleep pattern during pregnancy, 289 pregnant women were studied.

Subjective estimation form was developed including 3 major categories, namely, "Factors Relating to Sleep", "Factors Relating on Awaking Feeling", "Satisfaction resulting from Sleep". Influencing factors were also collected.

It was found that at the first trimester the desire for sleep increased. Towards the third trimester, feeling of difficult to fall in asleep, insufficient length of sleep, awaking during sleep were increased, and as a result, dissatisfaction towards sleep increased.

Among the primigravidae, rejective feeling to the awaking during sleep is strong in the first trimester, but gradually decreased toward second and third trimester. While rejective feeling of the multigravidae was just the same ratio with the third trimester of the primigravidae. This evidence suggests the primigravidae needs more time for adjustment to the pregnancy.

It was found physical discomfort due to the pregnancy influencing on satisfaction. Support provided by the family is another important influencing factor, to fall in sleep, depth of sleep, and feeling of satisfaction. 


\section{I はじめに}

睡眠は健康生活に欠くことのできない欲求であ リ，その睡眠パターンや様相は量的にも質的にも， 個人の心身の健康状態や環境に応じて变化する。 睡眠サイクルの乱れや睡眠の中断が心身の健康生 活を阻害することは鳥居1), 新福 ${ }^{2)}$, Meddis $^{3)}$ ほか によって，数多く報告されている。

睡眠が女性の月経周期に伴って, あるいは妊娠 中に変化することは経験的に知られている現象で ある。しかし，それを理由に，この変動要因の大 きい女性は睡眠研究対象から除外されることが多 かった。妊娠中の睡眠に関する基礎的研究を行う こ上は, 助産婦が妊婦を理解するのに役立つと考 えた。

\section{II 本研究の概念枠組}

人間の睡眠は，複雑多岐にわたる要因の影響を 受け，そ机は身体的のみならず心理，社会的影響 を受けて存在する生活現象である。

人が快い，満足した眠りを得たかどうかは, 睡 眠脳波老用いて生理学的な客観的側面から分析す ることができる。それと同時に，熟睡感の有無や 起休時の体調の良否等の主観的評価で現すことも できる。睡眠はこの生理学的指標と主観的評価の 2 側面がからみあった総合的なものであると考之 る。本研究においては，次のように概念枠組を設 定した (図1参照)。

睡眠の主観的評価とは，その人が睡眠に対して もつている心理的体験の叙述である。睡眠はその 経過から考えて「入眠および睡眠中の関連因子群」 (A) 掞よび「起床時の関連因子群」(B)が関与して，そ の結果として「睡眠全体の満足度」(C)があると仮定 した。

「入眠および睡眠中の関連因子群」は次の 1) ～4）で構成され，1）入眠の難易度，2）時間 の垃さ，3）眠りの深さ，4）途中覚醒状態であ り，特に4）はマイナスの側面として考えた。ま た, 「起床時の関連因子群」は，1）起床の難易度 上2）起床時の気分で構成し，(A)と(B)の総和が, 絬果として「快い，よい睡眠，満足した眠り」(C)の 状態をもたらすと考えた。

その考えをもとに，今问はこれらの睡眠を構成

\section{A. 入眠および睡眠中の関連因子群}

1. 入眠の難易度

(寝つき)

2. 時間の長さ— 4 。途中覚醒状況 (回数・時刻・

3. 眼りの深さ 理由・覚醒状沉)

\section{B. 起床時の関連因子群}

1。起床の難易度

(寝起き)

2. 起休時の気分

(夾快さ・疲労回復感・熟眠感)

c.

睡眠全体の満足度

図 1 睡眠の満足に関する関連因子群

する要素が, 妊娠の進行に伴ってよ゙のように推移 するかに焦点をあて，分析した。

\section{III 目 的}

1. 好婦の睡眠の満足にはどのような睡眠関連 因子群が関与しているのかを明らかにする。

2. 妊娠の進行に伴って，そ机ぞれの睡眠関連 因子がどのような变化をしているのかを明らかに する。

\section{IV 対 象}

都内の公立の一産院で奸娠中の管理を受けてい る妊婦を対象とした。研究への協力を承諾した妊 婦に「妊娠中の睡眠に関する調省」の用紙を配布 し，自己記入式調査を行った。

調査票は294例に配布し，有効问答として289例 (98.3\%) を得た。

対象の年柃・産歴・妊娠週数別の特性は表 1 に 示すとおりである。对象の第 1 子および第 2 子出 産年齢は, 昭和61年度全国平均值 ${ }^{4)}$ とほぼ一致し ていた。

\section{V 方 法}

1. 調査票の作成（付録参照） 
表 1 年龄 - 産歴- 妊娠週数別対象妊婦数

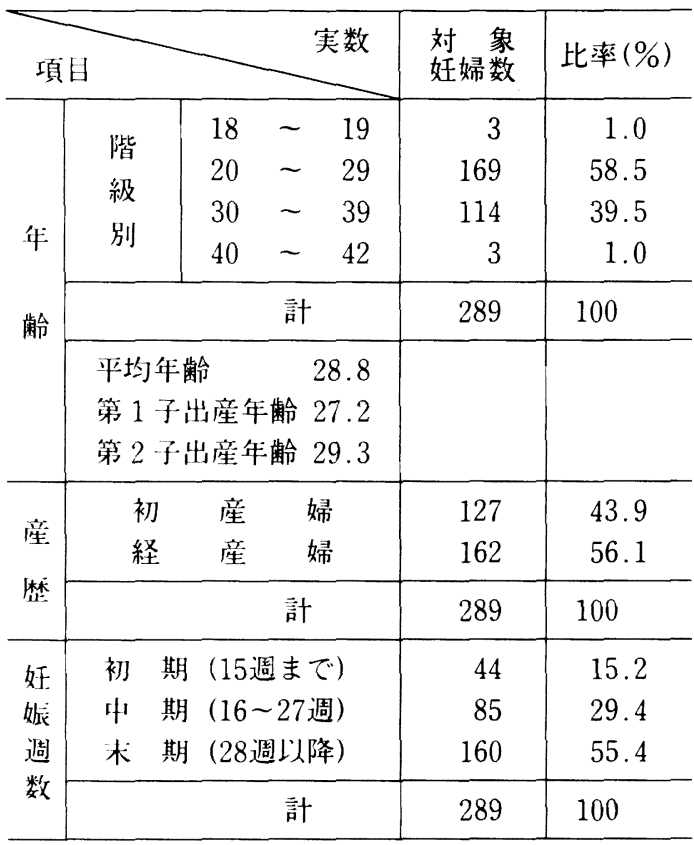

調査票の作成にあたっては、小栗ららの青年男 子445名を対象とした睡眠感調査を参考とした。特 に睡眠の構成因子のうち，項目分析でその弁別力 において保証されていた項目の要素を取り入れ た。さらに, 睡眠研究の専門家からの助言を得て, 以下のように調査票を作成した。

「入眠および睡眠中の関連因子群」は, 最近の睡 眠に関して回答を求め, 入眠の難易度（寝つき）・ 時間の長さ・眠りの深さの評価尺度としては，S D法による 7 点尺度を作成した。

睡眠中の途中党醒については，一晚の就床から 起床までの時刻・途中覚醒の時刻および理由と目 覚めた時の主観的な状態について記入する調査票 を考案した。さらに途中覚醒後の再入眠の難易度 はS D法による 7 点尺度とした。また途中覚醒に 対する肯定・否定的な感情を八つに分類した項目 を設けた。

「起床時の関連因子群」は, 起床の難易度（寝起 き）を三つの困難さの程度として分類した。起床 時の気分については爽快さ・熟睡感・疲労回復感 に関してそれぞれ2項目ずつ設け，Likert 法によ る4 点尺度を作成した。

「睡眠全体の満足度」は, 満足の程度を S D 法に よる 7 点尺度とした。
「最近の睡眠」として，最もふつうの生活状態に おける睡眠を選び，調査票に回答を求めた。さら に本人の睡眠変化を知るために, 調查時の睡眠と 3〜4 か月前の睡眠とを比較して，寝つき・時間 の長さ・眠りの深さ・途中覚醒の回数・起床時の 気分について, その変化についての回答を求めた。 「睡眠に関する影響因子」は, 睡眠に関する工夫・ 家族のサポート・睡眠変化の予測度・身体的不調・ 心理的恼みについての有無とその内容に関して回 答を求めた。その他に個人特性を加え, 無記名回 答とした。

\section{2. 調查方法}

該当する妊婦にプリテストを実施し，調査票の 設問事項の䏴除や, 設問表現および構成の修正を 行った。調查票は, 昭和62年 6 月 15 日から 30 日ま

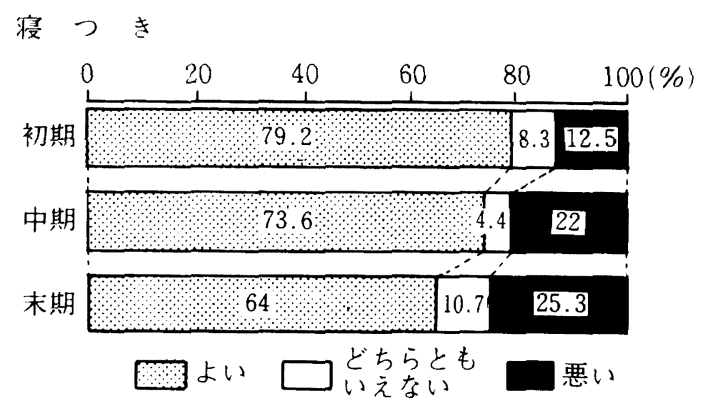

睡眠時間の長さ

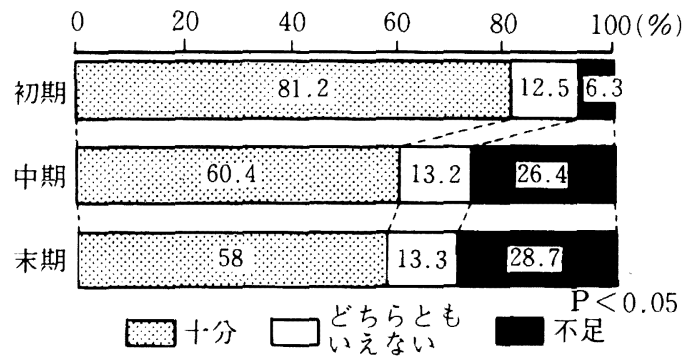

睡眠の深さ

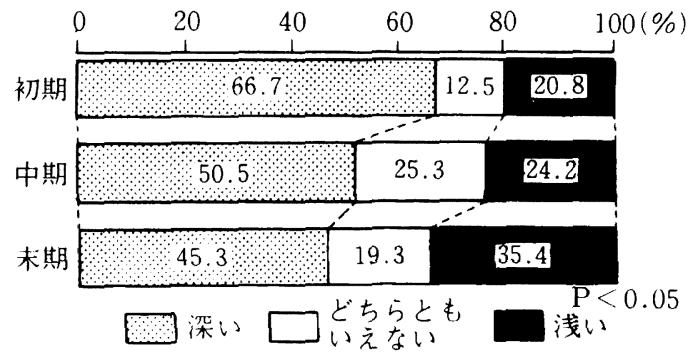

図 2 好娠時期別, 睡眠の寝つき・時間・深さの評価 
での間に好婦外来で対象者に手交配布し，その場 で記入後, 回収した。

\section{3. 分析方法}

デー夕は、妊娠週数別の睡眠に関する関連因子 について頻度を求め, 調査項目に含めた S D, Likert 尺度は、1 段階を 1 点として点数化した。1 晚の睡眠経過については、経時的に途中覚醒の理 由と状態を集計した。(A)(B)(C)の関連因子群間の関 係については, 数量化 3 類を適用して分析した。

\section{VI 結 果}

\section{1.「入眠および睡眠中の関連因子群」(A)}

1) 寝つき・時間の長さ・深さ

妊娠時期別に入眠の難易度の指標として寝つき をみると，図2のように「よい」と回答する比率 は初期群が中期, 末期に比べてやや多いが, 有意 な差はなかった。眠るための工夫を特別に行って いる者は64例（全体の $22.1 \%$ ）であり，工夫の内 容は，環境の調整・就床前の入浴・眠りに影響を 与之る刺激物の飲食を避けることが多く行われて いた。

睡眠時間の長さは, 「不足」と回答する比率が初 期群の $6.3 \%$ に比べて, 中期群・末期群ではそれぞ れ $26.4 \% ， 28.7 \%$ あ゙あ，有意に高い結果であっ た(図 2 参照)。

昼寝を除く睡眠実時間数は, 初期群の平均 7 時 間37分に対し，中期群は 7 時間21分，末期群は 7 時間 4 分であり, 妊娠の進行に伴って漸次, 減少 していた。各群間の差をみると, 初期群と中期群, 中期群と末期群の間には差は認められず, 初期群 と末期群の間には, 有意な差が $(\mathrm{t}=2.88 \quad \mathrm{p}<$ $0.01 ）$ 認められた。また昼寝状態は, 頻度・平均 時間数ともに末期群が中期群に比へてて有意に増加 している結果であった。

昼寝をする理由は，初期群と末期群で差があり $(\mathrm{p}<0.005)$, 初期群では「夜も昼も眠いから」と 回答する比率が $85 \%$ と多く,「夜眠れないから, 睡 眠不足を補う」の理由は少なく $15 \%$ にすぎないの に比へ，末期群では逆に「夜眠れないから, 睡眠 不足を補う」は $54.9 \%$ と增加していた。

眠りの深さが「浅い」と回答する者の比率は, 初期群 $20.8 \%$, 中期群 $24.2 \%$ であり, 末期群は 35.4 \%と多く,有意な差が認められた(図 2 参照)。

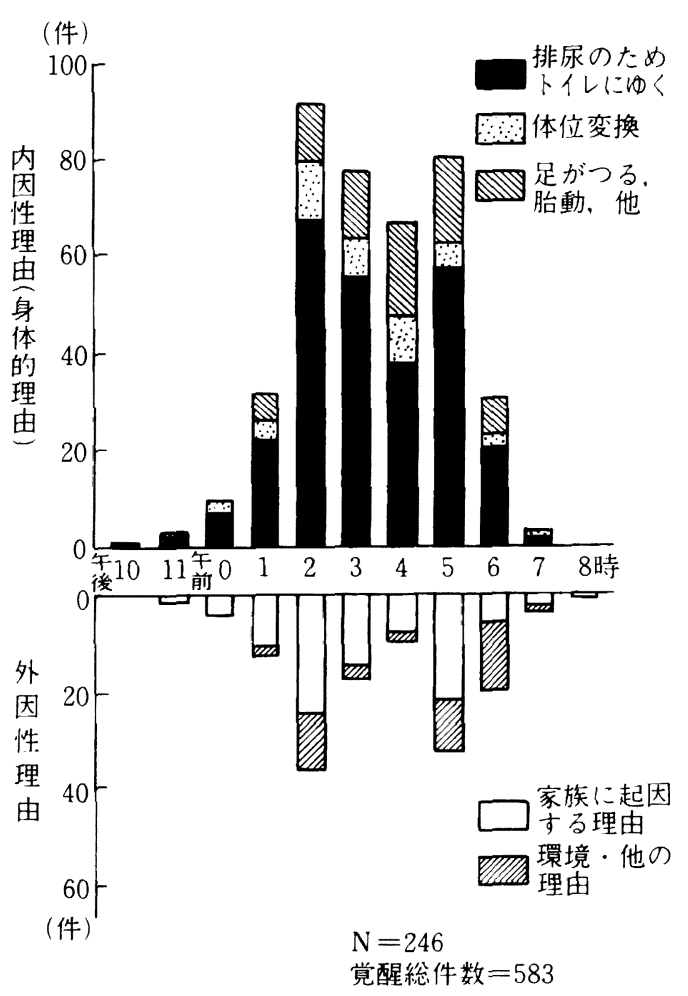

図 3 途中賞醒の時刻と理由

\section{2 ）途中覚醒}

睡眠全体の主観的経過からみると，就床時刻は 午後 8 時から午前 1 時の間に分布し,最頻値は午 後11時であった。起床時刻は午前 5 時から10時の 間に分布し，最頻値は午前 7 時であった。

睡眠中に途中覚醒のまったくない者は43例（全 体の $14.9 \%) て ゙ あ り ，$ 残りの246例は何回か夜中に 目覚めていた。この途中覚醒の回数をみると、1 回から 5 回の範囲であり, 平均1.8回で, 1 回から 3 回までの累積比率は $98 \%$ に達していた。

途中覚醒のあった 246 例について経時的に賞醒 時刻と理由をみると (図3 参照)，妊婦自身の内因 性理由が外因性の理由よりも多く認められた。

内因性の理由では，身体的理由（392件）「排尿 のため」,「体位変換」,「足のこむらがえり」が多 く, 覚醒時刻は午前 2 時と 5 時にピークがあった。 妊娠時期別にみると, 初期群では87.5\%が「排尿」 を挙げているが，末期群では「排尿」 $61.8 \%$,「体 位変換」 $16.9 \%$ ，「こむらがえり」 $8.4 \%$ と排尿以 外の妊娠性変化の理由も挙げられていた。 

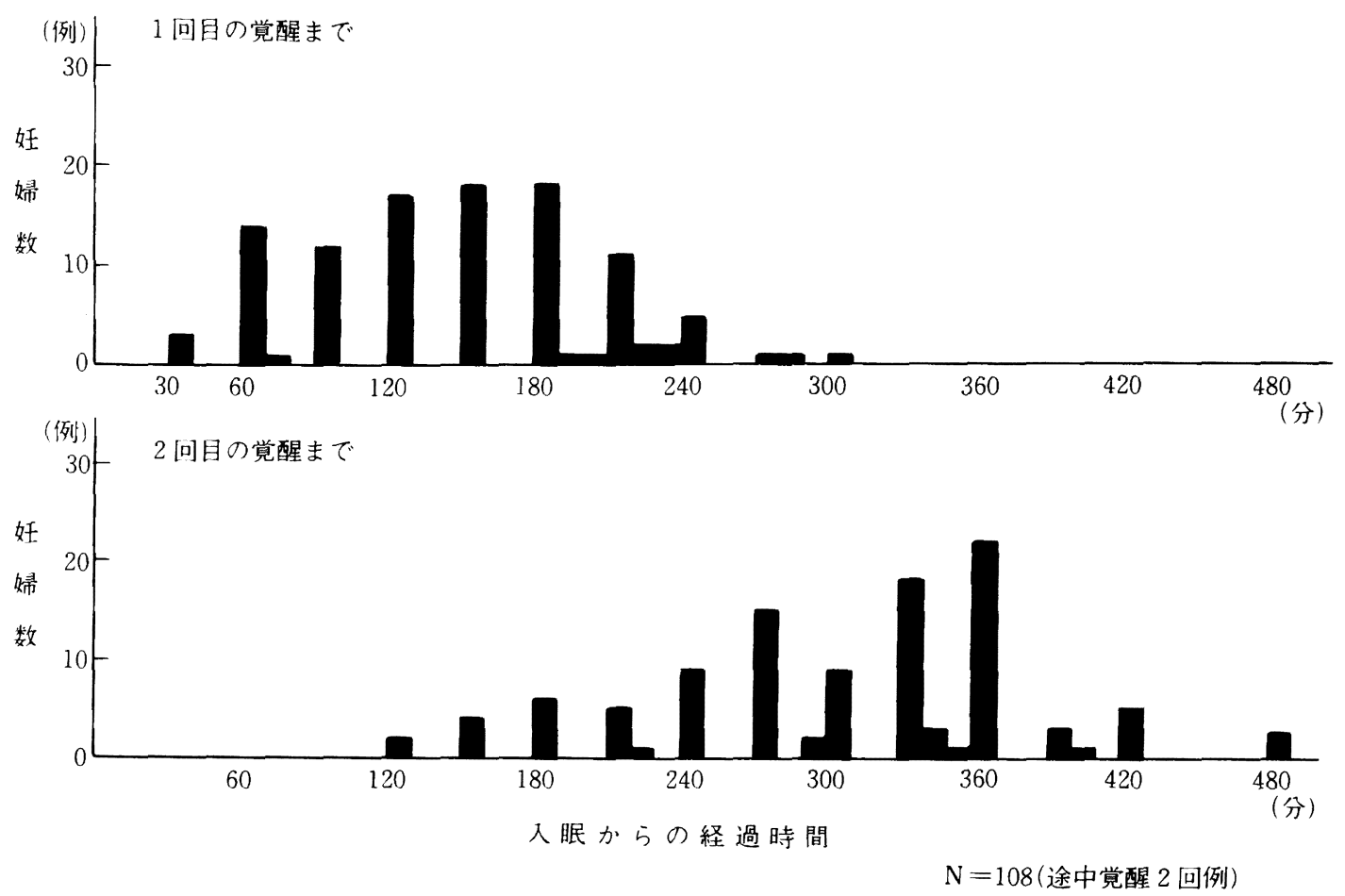

図4入眠から覚醒までの経過時間別妊婦数

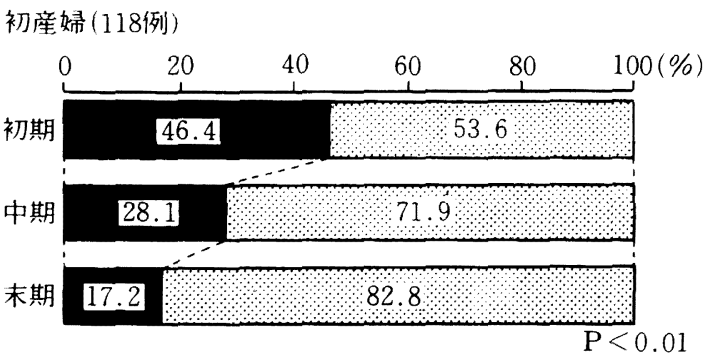

経産婦 (156例)

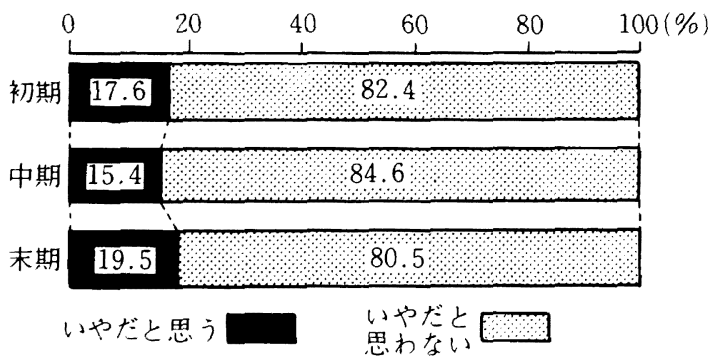

図 5 産歴別, 途中覚醒に対する感情の比率

一方外因性の理由では, 家族に起因する理由 (95 件), 環境的理由（39件）が挙げられていた。

睡眠中に 2 回の途中覚醒のあった108例につい て, 入眠から党醒までの経過時間を図 4 に示した。

1 回目の覚醒は, 入眠から $2 \sim 3$ 時間目にピー クがあり, 2 回目の党醒は5.5〜 6 時間目に集中し ていた。一晚の睡眠経過を前半と後半に大別し， 前半期に当たる部分で目覚めている第 1 回目の覚 醒と、睡眠後半期に当たる 2 回目の覚醒との相違 を，その目覚めた時の主観的な状態像でみると有 意な差（ $\mathrm{p}<0.05 ）$ が認められた。

第 1 回目の覚醒では「頭がぼんやりしている」 比率 $(70.7 \%)$ が「はっきり」(29.3\%)の 2 倍以 上あるが，第 2 回目の覚醒では「ぼんやり」の比 率 $(49.2 \%)$ に対して，「はっきり」の比率は 50.8 \%と增加していた。

妊娠週数別の途中覚醒の回数を，その $3 \sim 4$ か 月前の睡眠と比較して変化の推移を分析した。途 中党醒の回数が「いまのほうが多い」と評価する 人は, 妊娠初期群 $61.3 \%$, 末期群 $61.3 \%$ と中期 (42.7\%) に比へ有意（ $\mathrm{p}<0.004 ） に$ 高かった。

これらの夜中の途中党醒に対する感情では,「し 


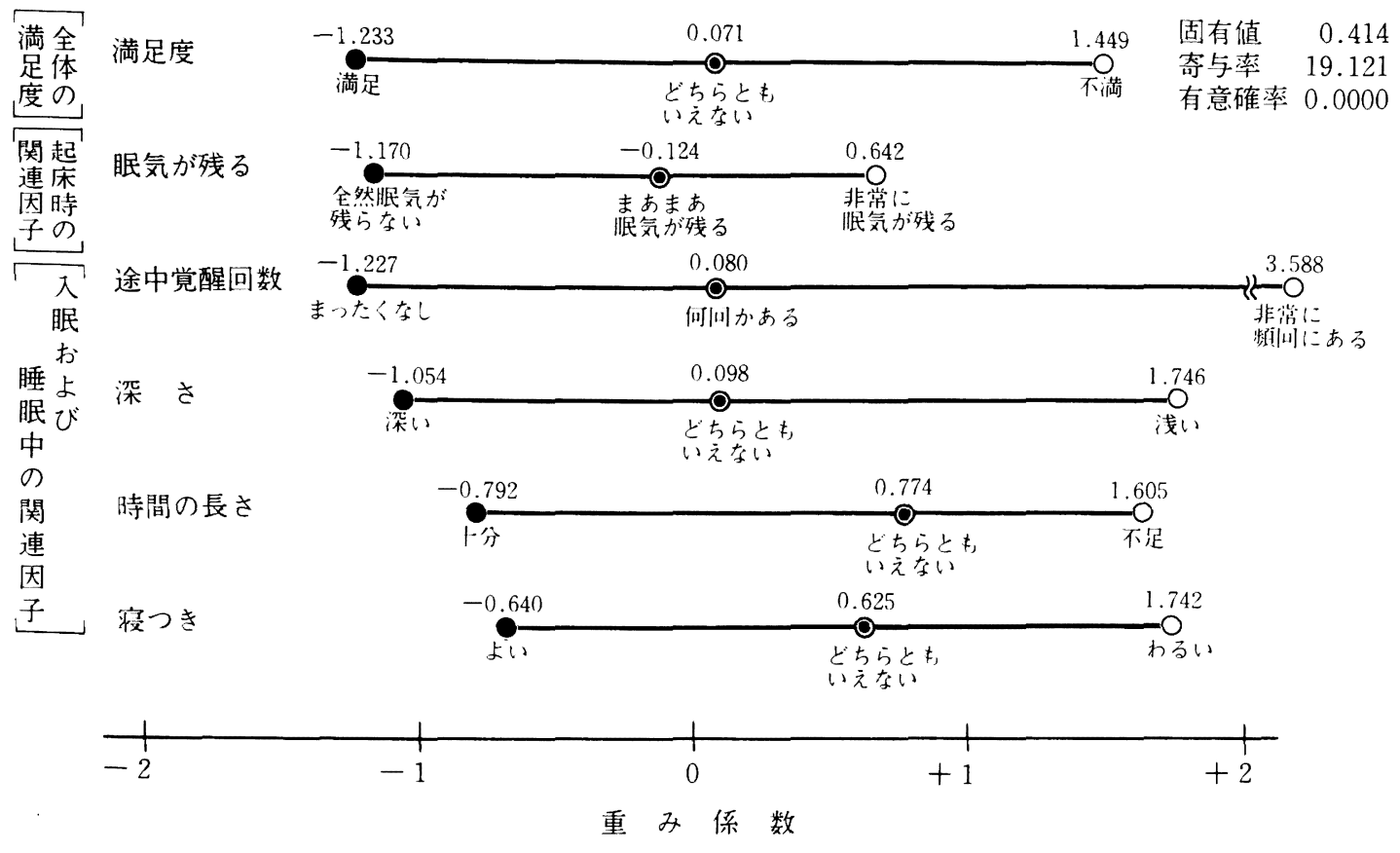

図 6 睡眠全体に関する因子の関係（数量化 3 類）

かたがない」が半数にみられた。「いやだ」という 否定的回答は、初産婦においては初期群が, 中期 群・末期群に比べて有意に多く認められた。一方, 経産婦では時期別に差はなく，いずれの時期も初 産婦の末期群と近似した比率であった（図 5 参 照)。

\section{2.「起床時の睡眠関連因子群」(B)}

1) 起床時の状況

起床の難易度の指標としての寝起きでは,「なか なか起きることができない」と回答する比率が初 期群 $26.2 \%$, 中期群 $7.2 \%$, 末期群 $5.7 \%$ で初期群に 有意 $(\mathrm{p}<0.001)$ に高かった。

さらに起床時の気分のうち「眠気が残る」は, 初期・末期が中期に比べて有意に高い傾向があっ た。各群の睡眠と $3 \sim 4$ か月前の睡眠の比較では, 起床時の気分は「いまのほうが悪い」と回答する 比率が初期群に有意 $(\mathrm{p}<0.001)$ に高かった。

3.「睡眠全体の満足度」(C)

「入眠および睡眠中の関連因子群」および「起床 時の関連因子群」と「睡眠全体の満足度」との関 係を数量化 3 類を用いて分析した。第 1 軸に抽出 された成分は図 6 に示した。各カテゴリ一の重み 係数は，負の領域には睡眠が良好・満足な状態が 位置し，正の領域には睡眠が不良・不満足な状態
が位置していた。

つまり、睡眠が満足であることとは，寝つきが よく, 時間が十分であり, 眠りの深さが深く, 途 中覚醒がなく，起床時の気分として眠気がまった く残らないという因子との間に関係があることを 示していた。

妊娠週数を初期・中期・末期の 3 カテゴリーに 分けて同様の分析をすると，妊娠初期に関連した 因子は負の領域に位置し，妊娠末期に関連した因 子は正の領域に位置していた。

\section{4. 睡眠に関する影響因子}

\section{1) 家族のサポート}

「夜中の途中賞醒や眠りについて気づかってくれ る人がいるか」の問いに対して，「いる」と回答し たのは205例(全体の70.9\%)，「いない」は78例 (27 \%)であった。気づかってくれる人では，夫が最 も多く，次いで実母であった。

このような家族の気づかい（サポート）に対し ての満足度を聞くと,『サポートあり』の群では「満 足」が $80.4 \%$ に対して，『サポートなし』の群では $20 \%$ にすぎず，有意な差が認められた（ $\mathrm{p}<$ $0.00001)$ 。

次に, この家族のサポートに対する満足度別に 睡眠の関連因子をみると，「寝つきが悪い」と「眠 
睡眠の深さ

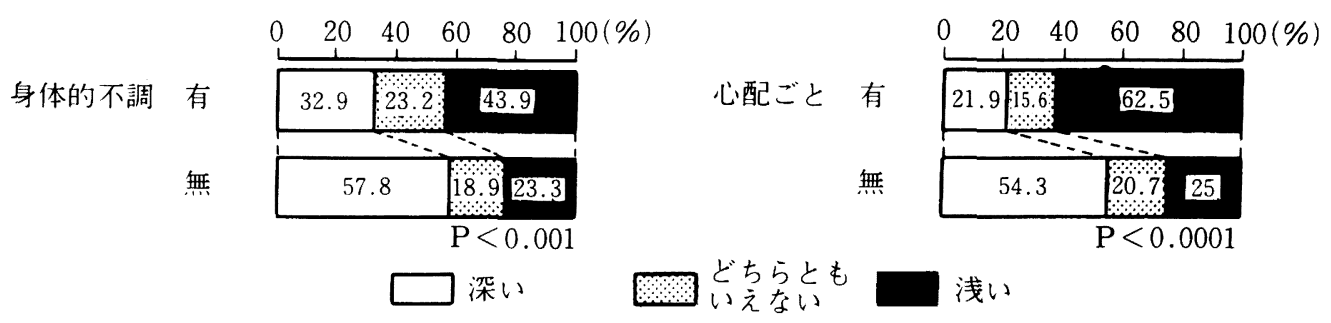

睡眠全体の満足度

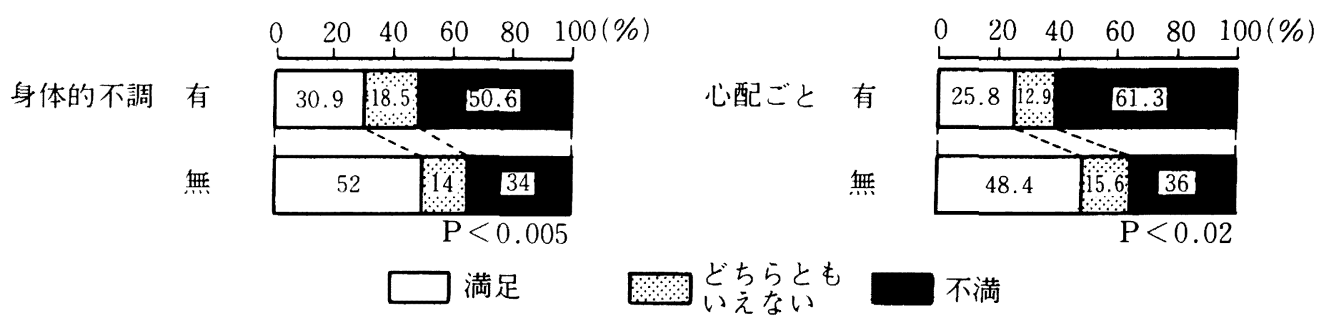

図 7 身体的不調・心配ごとの有無別, 睡眠の深さ・満足度の評価

りの深さが浅い」に対する比率が不満足群に有意 に高率であった。

さらに, 同居中の家族のために, 妊婦が夜中に 起きて世話をする必要性がある人は，72例（全体 の24.9\%) に認められた。この夜中の世話の必要 性の有無は、産歴と関係が認められ，経産婦にそ の必要性ありと回答する比率は圧倒的に高率であ つた。また,『夜中の世話の必要性がある群』は, 「夜中の途中覚醒後の寝つき」が悪いと回答するも のが $25.0 \%$ と,『必要性のない群』の15.5\%に比べ て有意 $(\mathrm{p}<0.05)$ に高かった。

同様に睡眠全体の満足度も『世話の必要性のあ る群』は $31.9 \%$ で,『必要性のない群』の53.3\%に 比べて有意 $(\mathrm{p}<0.01)$ に低かった。

\section{2 ）睡眠変化の予測}

妊娠すると睡眠は変化すると予測していたかど うかは，「予測していた」206例 (71.3\%)，「予測 していなかった」83例 (28.7\%) であり，初経産 歴別では初産婦のほうに「予測していなかった」 の比率は有意に高かった $(\mathrm{p}<0.0000)$ 。

3 ) 身体的不調, 心配ごと

身体の不調で眠れなくなることのある人は82例 あり，内容には腹部の緊張・重圧感・腰痛・こむ らがえり・胎動を多く挙げていた。
眠れなくなるような恼みや心配ごとのある人は 32例あり, 内容は, 流早産の心配や家族のこと, 分 婏に対する不安や産後の生活への不安であった。

身体的不調の有無および心配ごとの有無と睡眠 関連因子をみると、いずれも身体不調や心配ごと のある群は，「眠りの深さ」が浅い，「睡眠全体の 満足度」も不満と回答する比率が, 身体不調や心 配ごとのない群より有意に高率であった（図 7 参 照)。

\section{VII 考 察}

本研究では，睡眠の主観的評価を構成する要因 として「入眠および睡眠中の関連因子群」と「起 床時の関連因子群」を挙げ，それらの総合的な結 果として「睡眠全体の満足度」が影響を受けるこ とがわかった。心地よい眠りを構成するのは，寝 つきがよく，眠りの深さが深く，時間が十分であ り，途中覚醒がなく，起床時には眠気が残らない ことが寄与していた。

睡眠が妊娠の進行に伴ってどのように変化する かをみると、従来は，妊娠初期には, estrogen, progesteronの増加をはじめとして，急激な内分 泌環境の変化が起こるため, 基礎代謝の克進や血 糖値の低下などから疲労感が生ずると指摘されて 


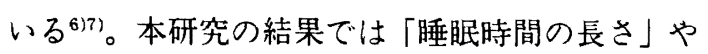
「昼寝の理由」,「起床の難易」,「起床時の気分」の 点から, 好娠初期群に眠りに対する欲求が強いこ とが推察された。中期になると初期に比べて，睡 眠に対する欲求は落ち着きをみせていた。妊娠末 期になると，本研究の結果では，寝つきが悪くな り，眠りが浅くなり，睡眠時間も不足するという 関係が示唆された。

Karacan ら ${ }^{8)}$ は, 妊娠末期から産裾にかけての 追跡調査で，妊娠に伴う睡眠の変化は、寝つきが 悪くなり，頻回に覚醒し、全体の時間が短縮する と述べ, estrogen. progesteron との関係を示唆し ている。同様の結果を Petre-Quadens ら ${ }^{9)}$ も報告 している。

睡眠を中断する身体的理由として，增大した子 宮による圧迫のための頻尿や体位变換の困難さな どによる睡眠の問題はVarneyによって報告さ れ(0)，また保健面接の場面で訴えられるので経馻 的に知られている。本研究の結果でも，途中覚醒 の理由として多かったのは外因性の理由よりむし ろ好婦自身の内因性の身体的理由であり，特に初 期に「排尿」，末期には「排尿」，「体位変換」，「足 のこむらがえり」であった。これらの症状は妊婦 の不快症状として従来から指摘されていたことで あり，睡眠への影響を改めて確認した。

さらに途中覚醒の感情として, 初産婦群では初 期群に「いやだ」という否定的回答が多く，中期・ 末期と妊娠が進行するにつれて，その比率が減少 していることは，睡眠変化を含む妊娠の適応には 時間が必要であることを示唆している。

好娠による身体的変化は，同時に心理に影響す る。妊婦の眠りに対する家族の気づかい・サポー トの有無が睡眠の主観的評価に影響を与えてい た。好娠中は,心理的に vulnerable stage（傷つ きやすい時期）と呼ばれているだけに，睡眠に影 響する心理的因子も重要であると思われる。

\section{VIIII ケアへの示唆}

妊娠期の睡眠変化の調査結果をもとに，妊婦の 基本的生活の一側面である睡眠をアセスメントす る際の情報カテゴリーとして,「寝つき」,「深さ」, 「時間の十分さ」, 「途中覚醒状態」,「寝起き」, 「起 休時の気分」,「全体の満足度」の側面が手がかり
になると思われる。同時に影響因子としての身体 的不快症状・家族の茾ポートが挙げられる。

奵娠に伴って睡眠の変化は生理的・必然的に起 こることから，その変化について予期的に教育・ 指導寸ることは意味あることと思われる。これら の変化に, 初産婦は特に妊娠初期に強く反応する ことから，初産婦にはこの変化に先行して，妊娠 初期に生活指導することが必要であろう。

また姄娠末期には，夜間の不満足な唾眠を補う うえでも，昼閒の休息を適時勧めると同時に，足 のこむらがえり等不快症状に対して対処法を指導 し，それと闹時に眠りの変化が生理的な変化であ るこ上を説明する必要がある。

さらに㚥妮を取り巻く家族に対しては，妊娠に 俳い崜肶が変化してくること, 特に初期と末期に 起こる変化を家族が理解できるように教育し，心 理的なサポートを促す必要性がある。

今後, 産褯期にはどのような変化があるのか, 授乳上の関係を含めて解明していくことで, 妊娠 中からの予期的指導の手がかりを得ることができ ると考える。

\section{IX 結 論}

妊娠期における睡眠の主観的評価は,「入眠およ び睡眠中の関連因子群」と「起床時の関連因子群」 とが互いに関連し,「睡眠全体の満足度」を構成し ていた。

妊娠の進行に伴う変化では, 初期には非妊期に 比べて途中覚醒が多く、「眠い」という睡眠に対す る欲求が強く現れていた。中期になると, 初期に 比べて睡眠に対する欲求は落ち着きを示してい た。末期になると，葠つきが悪くなる・眠りが浅 くなる・時間が不足する。・途中覚醒が多くなると いう状態から，睡眠全体に不満感が高まるという 関係が示された。

\section{謝 辞}

稿を終わるに臨み、データ収集の場を提供して くださった, 東京都立築地産院院長柳田昌彦先生, 看護科長山崎サク氏に心から感謝します。さらに, 終始媓切にご指導いただいた東京都精神医学総合 研究所山本卓二先生に感謝します。また, 調査の 実施に聖路加看護大学小山真理子講師, 福地彰子 
講師, 岩澤和子講師, 前聖路加看護大学山本あい 子講師の多大なご協力のあったことをここに感謝 いたします。

本研究は昭和60年度文部省科学研究費N No.60440099 (研究代表者・近藤潤子) による研究の一部とし て行われたものである。

本研究の一部は、第29回日本母性衛生学会において 発表した。

\section{引用文献}

1. 鳥居鎮夫：行動としての睡眠, 188～206, 青上社, 1985。

2. 新福尚武: 睡服上人間, 105 167, 日本放送出版協会, 1982。

3. Meddis, Ray: The Sleep Instinct, 1977, 井上昆次郎' 訳、睡眠革命、157-188, 1985。

4. 厚生の指標, 国民衛生の動向一眧和63年, $35(9), 49$, 厚生統計協会，1988。

5. 小栗貢, 白川修一郎, 阿住一雄：睡眠感調查の続計的 解析, 臨休精神医学, 11，63～73，1982。

6. Jensen, M. D., Bobak, I. M. : Maternity and Gynecologic Care, 343, C. V. Mosby Company, 1985.
7. Clausen, J. P., et. al : Maternal Nursing Today, 305, McGraw-Hill Company,1977.

8. Karacan, I., Williams, R. L. et al. : Some Implications of the Sleep Patterns of Pregnancy for Postpartum Emotional Disturbances, British Journal of Psychiatry, 115, 929-935, 1969.

9. Petre-Quadens, O., De Barsy, A. M. et. al. : Sleep in Pregnancy, Evidence of Foetal-sleep Characteristics. J. neurol. Sci. 4.,600-605, 1967.

10. Varney H. : Nurse-Midwifery, 132, Blackwell Scientific Publications, 1987.

\section{参考文献}

・片・肙次郎：眠りの精を求めて〜今日の睡眠研究， $82-$ 83,どうぶつ社, 1986。

- Karacan, I., Heine, W., Agnew, H. W., Williams, R. L., Webb, W. B., and Ross, J. J. : Characteristics of Sleep Patterns during Late Pregnancy and the Postpartum Periods, Amer. J. Obstet. Gyn., 101,579$586,1968$.

・川上正澄：睡眠とホルモン,医学のあゆみ, 59(14), 898905, 1966。

- 大熊輝雄：睡眠の生理一最近の睡眠研究をめぐって一, (第16问日本小児神䅅学研究会特集), 脳と発達, 6(6), 422-433，1974。

・鳥居鎮夫：睡眠の科学, 浅倉書店, 1985。

\section{付 録}
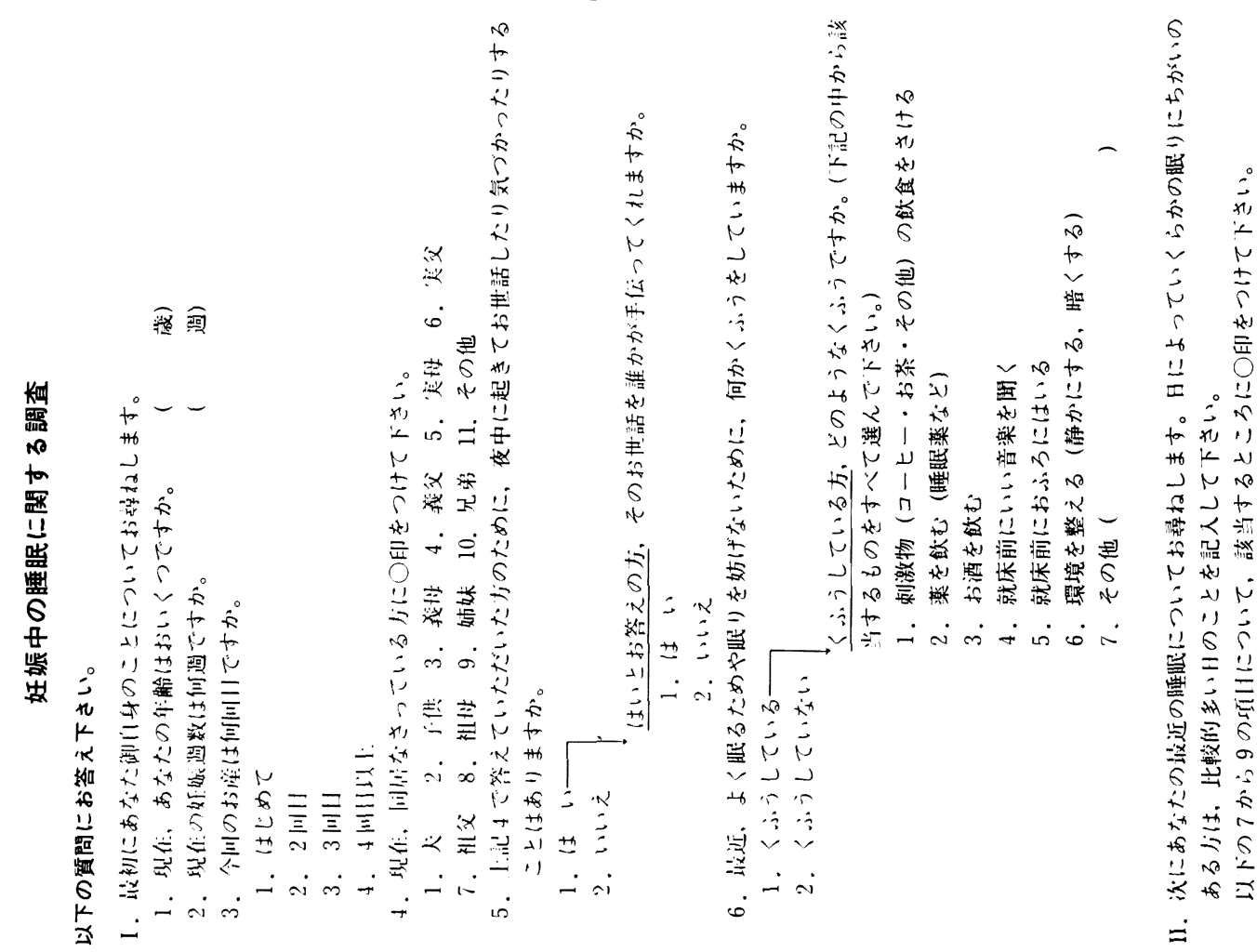

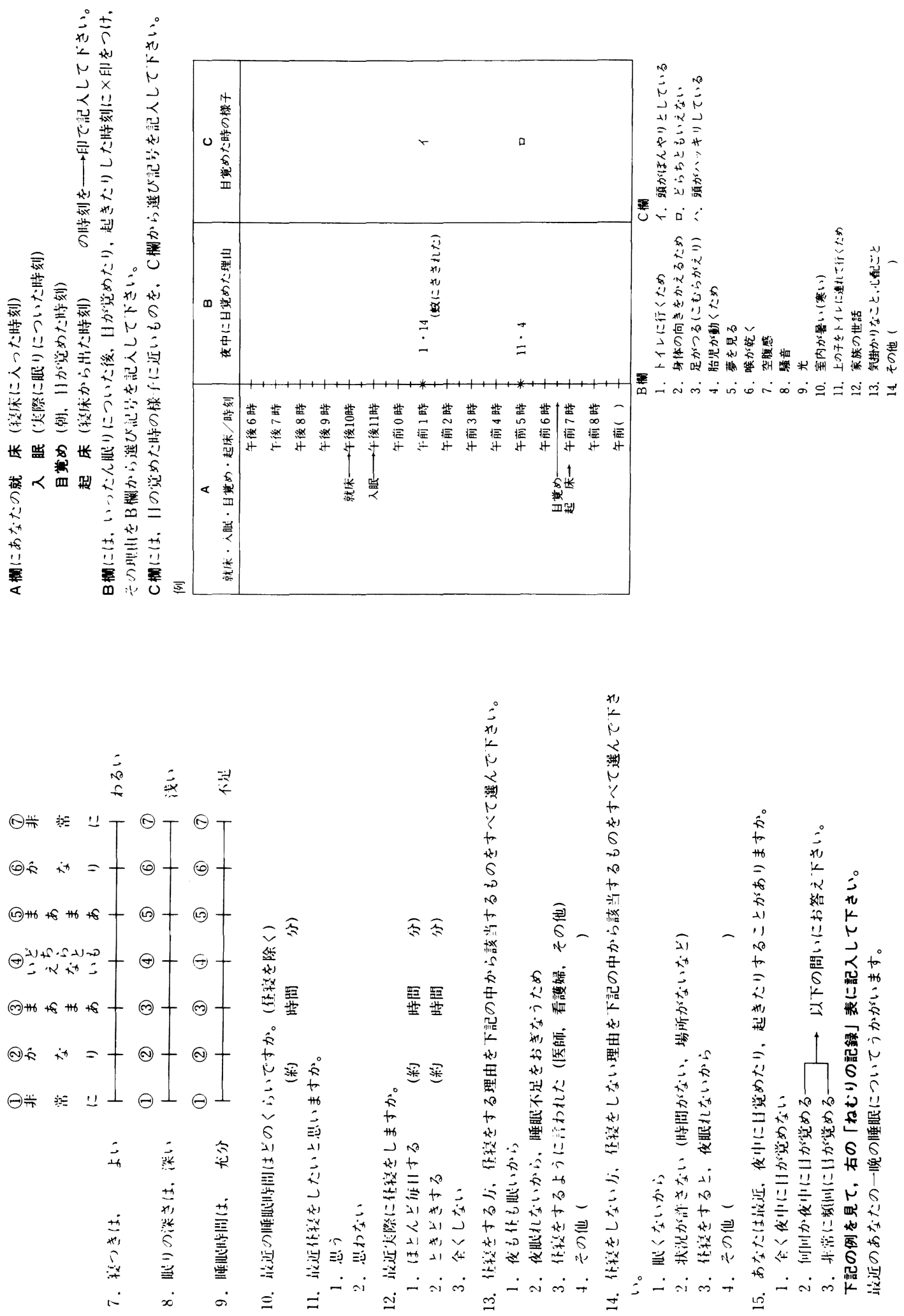

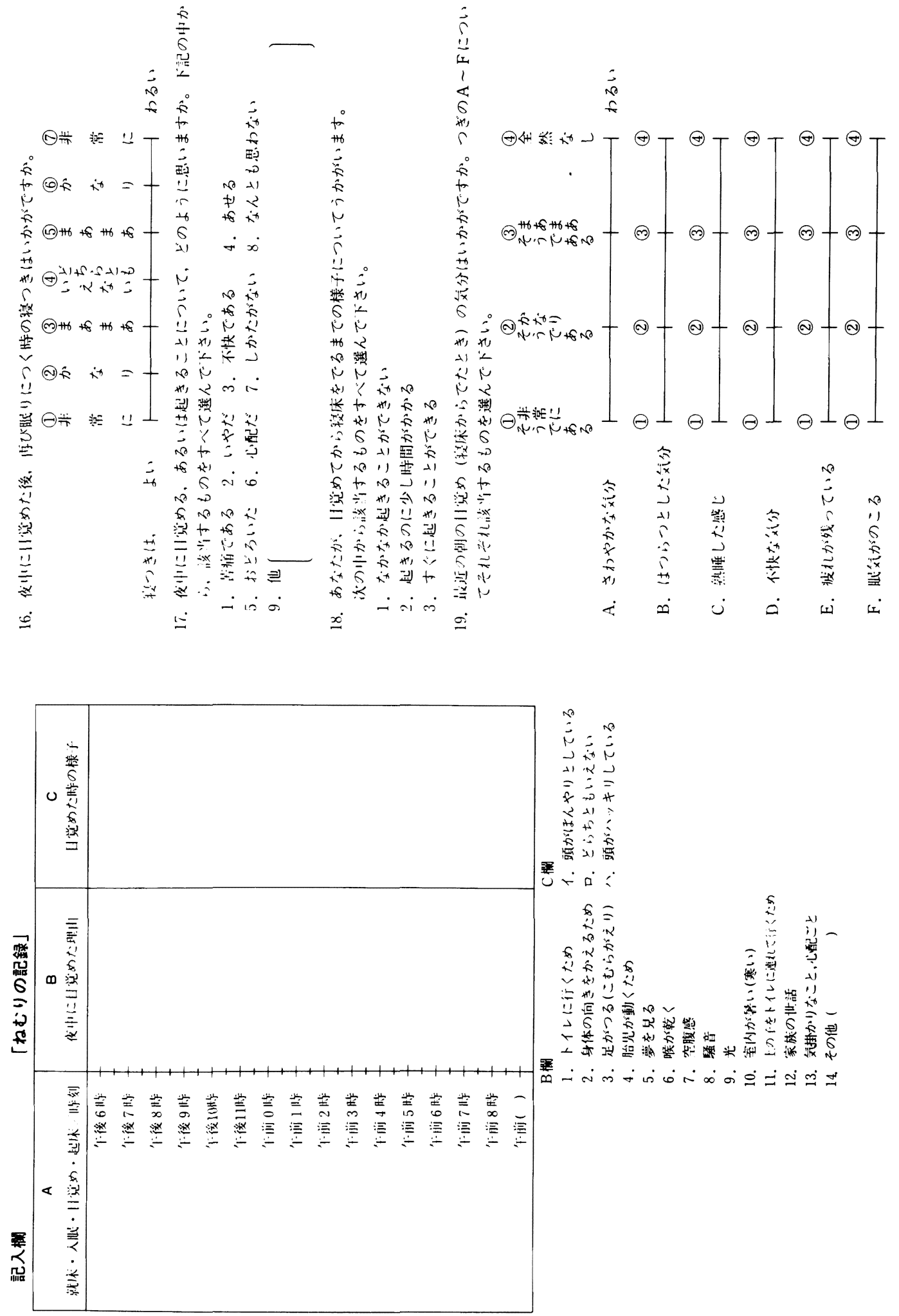

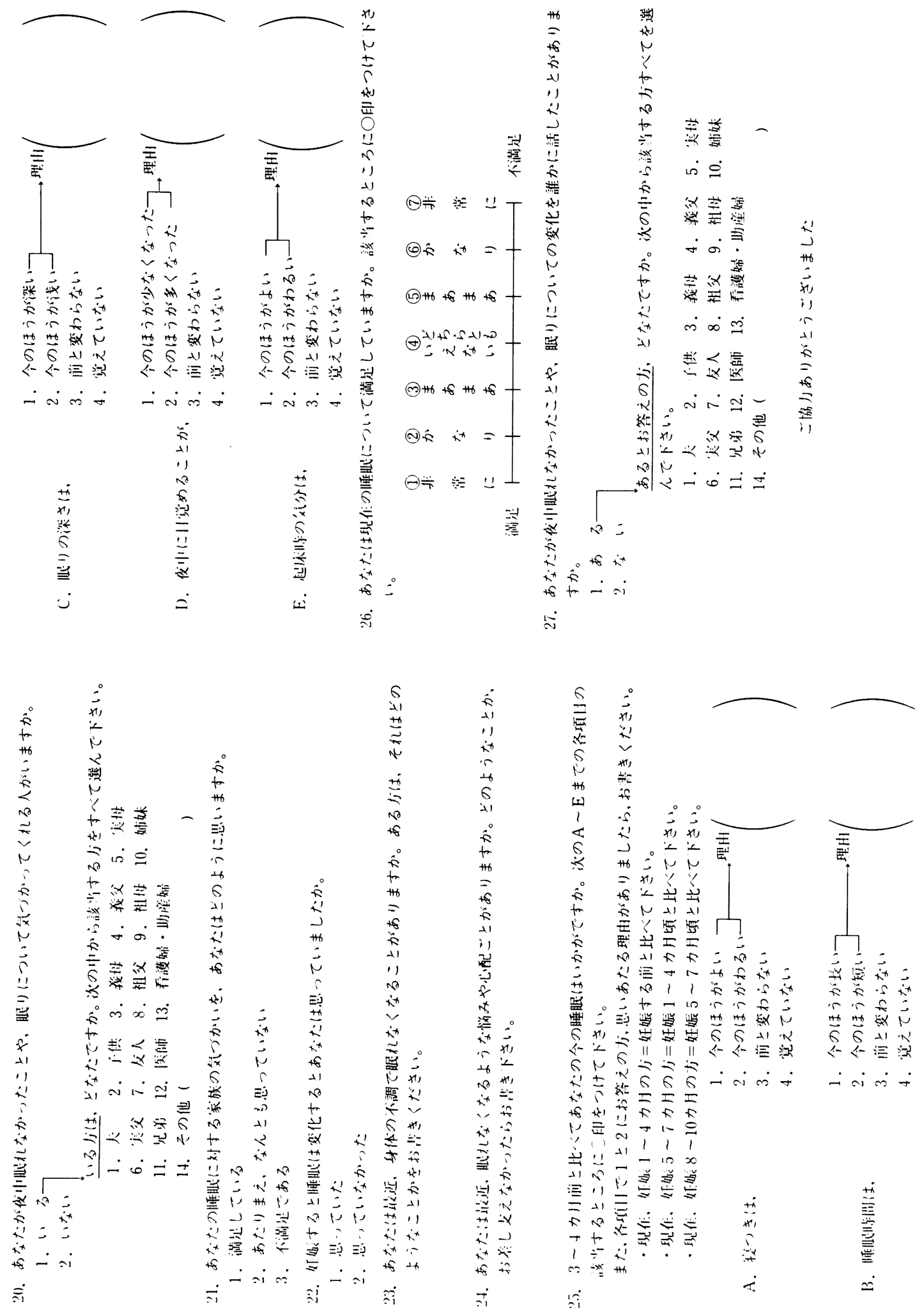